\title{
DISKRIMINASI PEREMPUAN BERCADAR DALAM PERSPEKTIF HEGEMONI
}

\author{
Nuryu Wahidah, \\ Universitas Muhammadiyah Malang \\ Nuryuwaidah1989@gmail.com \\ Ezzah Nuranisah \\ Universitas Muhammadiyah Malang \\ ezzahnuranissa@gmail.com
}

\begin{abstract}
This study aims to determine, describe, and explain people's perspectives on veiled women. The existence of community construction that veiled women are labeled as radicals, seen from the many historical phenomena about terrorism always related to women who use the veil. This study aims to look at discrimination against veiled women with a review of historical phenomenology in the study of hegemony. Through this research it can be seen that veiled women are labeled as radicals and terrorists. The understanding of hegemony emphasizes that hegemony will take place if the way of life, way of thinking and views of the people below and governing are influenced by the elite and the mass media. There should be no discrimination against women of any age, religion, ethnicity and status. All must be treated equally, fairly, and do not distinguish between culture, ethnicity, religion and social status. Discrimination in the use of veils in Indonesia which led to a ban on the use of veils on campus which later arose a criticism of the veil ban through the perspective of hegemony theory
\end{abstract}

Keywords: Discrimination, Veiled Women, Hegemony of Power.

\begin{abstract}
Abstrak
Penelitian ini bertujuan untuk mengetahui, menggambarkan, dan menjelaskan perspektif masyarakat terhadap wanita bercadar. Adanya kontruksi masyarakat bahwa perempuan bercadar dilabeling sebagai kaum radikal, dilihat dari banyaknya fenomena histori tentang terorisme selalu berkaitan dengan perempuan yang menggunakan cadar. Penelitian ini bertujuan untuk melihat diskriminasi terhadap perempuan bercadar dengan tinjauan pendekatan kualitatif fenomenologi histori dalam kajian hegemoni. Melalui penelitian ini dapat diketahui bahwa perempuan bercadar dilebeling sebagai radikal dan teroris. Paham hegemoni menekankan bahwa hegemoni akan berlangsung apabila cara hidup, cara berfikir dan pandangan masyarakat bawah maupun memerintah dipengaruhi oleh kaum elit dan media massa. Semestinya tidak ada diskriminasi terhadap perempuan yang berusia apapun, beragama apapun, bersuku apapun dan berstatus apapun. Semuanya harus diperlakukan secara setara, adil, dan tidak membedakan budaya, suku, agama dan status social. Diskriminasi penggunaan cadar di Indonesia yang menimbulkan larangan penggunaan cadar di kampus yang kemudian timbul sebuah kritik terhadap larangan bercadar tersebut melalui perspektif teori hegemoni
\end{abstract}

Kata Kunci: Diskriminasi, Perempuan Bercadar, Hegemoni Kekuasaan.

\section{PENDAHULUAN}

Diskriminasi terhadap pengguna cadar di Indonesia sudah menjadi bahan pembicaraan dan bahan pertimbangan pemerintah dan negara, dengan adanya argument Menteri Agama fakhrurrazi yang disiarkan oleh salah satu media televisi kompas pada tanggal 31 oktober 2019 tentang soal pelarangan penggunaan cadar di instansi pemerintah, "penggunaan cadar bukan budaya orang Indonesia dan dapat menimbulkan kecurigaan karena sering dikaitkan dengan paham tertentu sebaiknya penggunaan pakaian disesuaikan dengan budaya di 
Indonesia dengan mengatur cara berpakaian bagi aparatur sipil negara”. Bagi masyarakat Indonesia saat ini cadar bukan suatu hal yang baru, karena masyarakat Indonesia merupakan masyarakat yang mayoritas penduduknya adalah beragama Islam. Sehingga tak jarang dijumpai perempuan yang menggunakan cadar dalam kehidupan dan aktifitas sehari-harinya. Namun, persepsi masyarakat terhadap perempuan muslim yang menggunakan cadar sering dianggap sebagai sikap fanatisme terhadap agama bahkan tidak jarang juga mereka dikaitkan dengan kelompok islam radikal ${ }^{12}$. Muslim di Indonesia banyak menganut faham- faham tertentu sehingga walaupun sesama muslim, mereka akan berbeda apabila menganut paham yang berbeda, baik dalam berbusana maupun cara bergaul mereka di dalam kehidupan social $^{34}$

Dari perkembangan budaya, jilbab memiliki potensi diterima oleh sebagian masyarakat, sayangnya tidak demikian dengan cadar. Apalagi paska aksi terorisme, perempuan bercadar serta merta memiliki keterbatasan baru, tidak hanya harus menerima 'kodrat' sebagai perempuan, bentuk diskriminasi baru, baik secara eksplisit maupun implisit menjadi hal yang tak terelakkan, artinya perempuan bercadar mengalami diskriminasi berganda ${ }^{56}$. Dalam konteks sosial, keberadaan perempuan bercadar masih belum dapat diterima secara penuh oleh masyarakat. Terdapat persepsi sosial yang negatif terhadap prilaku bercadar yang mereka lakukan. Penggunaan cadar yang dilakukan oleh kaum perempuan tersebut dianggap mengganggu proses hubungan antar pribadi dalam bermasyarakat. Adanya anggapan bahwa penggunaan cadar sebagai hambatan untuk menciptakan keadaan yang lebih baik, dimana hubungan positif di antara masyarakat semakin sulit, karena melihat wajah adalah sesuatu yang fundamental dalam hubungan antar sesame ${ }^{78}$.

Penggunaan cadar bukan sekedar cara berbusana. Ia merupakan bentuk dari ekspresi identitas keagamaan. Karena itu perdebatan tentang pemakaian cadar di kalangan muslim Indonesia muncul terkait dengan perbedaan pemahaman dalam beragama dan sekaligus terkait dengan kesesuaian cara berpakaian demikian alam konteks Indonesia. Kontroversi penggunaan cadar semakin kuat terkait dengan sering munculnya para perempuan bercadar di media elektronik maupuncetak setiapkaliada pemberitaan tentang tersangka yang terlibat dalam tindakan terorisme 910. Hal ini menyebabkan kebijakan yang dikeluarkan cenderung memihak orang-orang yang memeluk Islam moderat dan menjadikan Islam Nusantara sebagai perspektif utama dan mendiskriminasi kelompok-kelompok Islam lainnya ${ }^{1112}$.

1 Khamdan Qolbi, "Makna Penggunaan Cadar Mahasiswi Institut Keislaman Abdullah Faqih ( INKAFA )," Jurnal Paradigma 1, no. 3 (2013): 1-4.

${ }^{2}$ Qolbi, K. (2013). Makna Penggunaan Cadar Mahasiswi Institut Keislaman Abdullah Faqih (INKAFA ). Jurnal Paradigma, 1(3), 1-4

3 Reni Juliani, "Stigmatisasi Mahasiswa Tentang Maraknya Mahasiswa Bercadar Di Kampus," Jurnal Community 4, no. 1 (2018): 90-104.

4Juliani, R. (2018). Stigmatisasi Mahasiswa Tentang Maraknya Mahasiswa Bercadar Di Kampus. Jurnal Community, 4(1), 90-104. https://doi.org/24775746

37.

5 Lintang Ratri, "Cadar, Media, Dan Identitas Perempuan Muslim," Topik Utama 39, no. 2 (2011): 29_

${ }^{6}$ Ratri, L. (2011). Cadar, Media, Dan Identitas Perempuan Muslim. Topik Utama, 39(2), 29-37.

7 Toha Andiko, "Larangan Bercadar Di Perguruan Tinggi Perspektif Sadd Al-Dzarî̀ah," Madania: Jurnal Kajian Keislaman 22, no. 1 (2018): 113.

8 Andiko, T. (2018). Larangan Bercadar di Perguruan Tinggi Perspektif Sadd al-Dzarîah. Madania: Jurnal Kajian Keislaman, 22(1), 113. https://doi.org/10.29300/madania.v22i1.993

9 Alif Fathur Rahman and Muhammad Syafiq, "Motivasi, Stigma Dan Coping Stigma Pada Perempuan Bercadar," Jurnal Psikologi Teori dan Terapan 7, no. 2 (2017): 103.

${ }^{10}$ Rahman, A. F., \& Syafiq, M. (2017). Motivasi, Stigma dan Coping Stigma pada Perempuan Bercadar. Jurnal Psikologi Teori Dan Terapan, 7(2), 103. https://doi.org/10.26740/jptt.v7n2.p103-115

11 Budi Kurniawan, "Rethinking Cadar Banning in Indonesia's Higher Education: Questioning 
Bagi sebagian umat Islam, cadar dianggap sebagai perintah Allah yang telah tercantum di dalam Kitab Suci Al-Qur'an. Namun banyak pula umat islam berpendapat bahwa apapun justifikasi terhadap cadar di masa lalu, hal itu tidak mempunyai relevansi sama sekali denganc zaman modern. Sementara kalangan umat Islam ortodoks, khususnya ulama, di sisi lain menganggap cadar bagi perempuan sebagai kebutuhan yang absolut dan menjalankannya dengan semua kekakuan yang bisa dilakukan.Karenanya, interaksi yang dibangun oleh perempuan bercadar, terkadang mendapat berbagai respon dari lingkungan social. Perempuan bercadar kerap mengalami kesulitan atau hambatan dalam proses komunikasi untuk membangun hubungan secara personal dengan masyakarat, hal ini yang menjadikan perempuan bercadar terkesan menutup diri dan dipandang negatif oleh masyarakat ${ }^{1314}$.

Tulisan ini menjelaskan bahwa bagaimana tindakan perempuan bercadar dalam pandangan masyarakat atas sikap dan perilaku yang berbeda sehingga melahirkan satu pernyataan diskriminasi baik oleh pihak elit, media massa, masayarakat bawah maupun lingkungan sosialnya. Gramsci melihat bahwa kelasa-kelas penguasa memaksakan visi hegemoni mereka melalaui berbagai institusi suprastruktural, seperti sekolah, media, agama dan praktek manusia sehari-hari (Bellamy, 1990) ${ }^{15}$. Tradisi cadar merupakan fenomena yang sering diperbincangakan di Indonesia. Ia dianggap merupakan bagian dari great tradition yang ada dalam Islam. Teori hegemoni melihat dunia melalui kacamata yang terdistorsi secara ideologis, sehingga seluruh pandangan dunianya harus ditentang sebelum revolusi bisa memperoleh dukungan massa (Bellamy, 1990) ${ }^{16}$. Namun, lebih dari itu, cadar juga berfungsi sebagai bahasa yang menyampaikan pesan-pesan budaya dan agama. Banyaknya fenomena penggunaan cadar yang diindentifikasikan sebagai kaum radikal membuat individu yang memakai cadar termarginalkan secara social.

Wanita muslim bercadar adalah mereka yang mengenakan "hijab" yang sesuai syar'i karena dilengkapi dengan kain penutup wajah, dan hanya menampakkan kedua mata ${ }^{1718}$. Abdul Halim Abu Syuqqah menyatakan bahwa cadar (niqab) merupakan bagian dari salah satu jenis pakaian yang digunakan oleh sebagian perempuan di masa Jahiliyah. Model pakaian ini telah berlangsung hingga masa Islam. Nabi Muhammad saw tidak mempermasalahkan model pakaian tersebut, tetapi tidak sampai mewajibkan, menghimbau ataupun menyunahkan cadar kepada perempuan. Seandainya cadar dianggap sebagai pakaian yang dapat menjaga marwah perempuan dan

Freedom of Religion and Positioning Fear of Radicalism," SHS Web of Conferences 54 (2018): 02004.

12 Kurniawan, B. (2018). Rethinking Cadar Banning in Indonesia's Higher Education: Questioning Freedom of Religion and Positioning Fear of Radicalism. SHS Web of Conferences, 54, 02004. https://doi.org/10.1051/shsconf/20185402004

13 Putri Aisyiyah Rachma Dewi, "Niqab Sebagai Fashion: Dialektik Konservatisme Dan Budaya Populer," Scriptura 9, no. 1 (2019): 9-15; Rosdalina Bukido Lisa Aisiyah Rasyid, "Problemtika Hukum Cadar Dalam Islam: Sebuah Tinjauan Normatif-Historis Problematics," Jurnal Ilmiah Al-Syir'ab 16, no. 1 (2018): 7492.

14 Dewi, P. A. R. (2019). Niqab Sebagai Fashion: Dialektik Konservatisme Dan Budaya Populer. Scriptura, 9(1), 9-15. https://doi.org/10.9744/scriptura.9.1.9-15

Lisa Aisiyah Rasyid, R. B. (2018). Problemtika hukum cadar dalam islam: sebuah tinjauan normatifhistoris Problematics. Jurnal Ilmiah Al-Syir'ah, 7492. https://doi.org/http://dx.doi.org/10.30984/jis.v16i1

15 Bellamy, Richard, 1990. Teori Sosial Modern: Modern Italia Social Theory Terjemahan Vedi R. Hadiz.Jakarta: LP3ES

${ }^{16} \mathrm{Ibid}$

${ }^{17}$ Lisa Aisiyah Rasyid, "Problemtika Hukum Cadar Dalam Islam: Sebuah Tinjauan Normatif-Historis Problematics."

${ }^{18}$ Lisa Aisiyah Rasyid, R. B. (2018). Problemtika hukum cadar dalam islam: sebuah tinjauan normatifhistoris Problematics. Jurnal Ilmiah Al-Syir'ah, $16(1), \quad 7492$. https://doi.org/http://dx.doi.org/10.30984/jis.v16i1 
sebagai sarana untuk menjaga keberlangsungan hidup mereka sebagaimana klaim sejumlah pihak, tentu Nabi Muhammad saw akan mewajibkannya kepada isteri-isterinya, karena mereka (isteri-isteri Nabi) adalah keluarga yang paling berhak untuk dijaga oleh Nabi. Namun kenyataannya justru Nabi tidak melalukannya. Ini juga tidak berlaku bagi sahabat-sahabat perempuan Nabi. Hal ini merupakan bukti bahwa cadar meskipun terus ada hingga di masa Islam sebagai jenis pakaian yang sudah dikenal dan dipakai oleh sebagian perempuan. Kemudian bagi ummahat al-mukminin (isteri-isteri Nabi) memiliki perbedaan, mereka dikhususkan atas kewajiban mengenakan hijab di dalam rumah dan menutup semua badan dan wajahnya ketika keluar dari rumah sebagai bentuk memperluas hijab yang diwajibkan di dalam rumah (Halim, 2008) ${ }^{19}$

Kesadaran teologis merupakan kesadaran yang berangkat dari nilai-nilai keTuhanan. Perempuan bercadar memiliki keyakinan bahwa menggunakan cadar menambahkan atribut baru dalam diri yang harus di implementasikan ke dalam aktivitas sehari-hari yaitu ketakwaan. Cadar selalu dilekatkan pada citra perempuan sholeha (yang bertakwa). Perempuan bercadar meyakini bahwa cadar itu yang terbaik. Menjadikan dirinya tidak menarik dimata laki-laki yang bukan muhrimnya justru menjadi tujuan, sesuatu yang tidak lazim bagi perempuan pada umumnya akibta adanya pandangan yang berbeda yang sudah terkonsep secara nasional maupun secara budaya.

Kesadaran teologis ini erat kaitannya dengan kesadaran normatif, yaitu sesuatu yang memandang agama dari segi ajarannya yang pokok dan asli dari Tuhan yang di dalamnya belum terdapat penalaran pemikiran manusia. Dalam pendekatan teologis ini agama dilihat sebagai suatu kebenaran mutlak dariTuhan.

Akibat adanya diskriminasi yang dilakukan oleh pemerintah dan masyarakat terhadap pengguna cadar menimbulkan permasalahan baru mengenai bagaimana tindakan perempuan yang bercadar mengarah pada tindakan radikal sehingga menimbulkan kontruksi radikal dari pemerintah, agama, sosial dan budaya indonesia itu sendiri. Tujuan dari penelitian adalah untuk dapat membuktikan bahwa perempuan bercadar bukan radikal, tetapi perempuan muslim yang menunjukan ketaatan terhadap ajaran agama islam. Hal ini dibuktikan dengan adanya isu peraturan menteri agama tentang larangan menggunakan cadar di lingkup Aparatur Sipil Negara. Penelitian ini menggunakan jenis penelitian deskriptif analitis yaitu dengan melihat fenomena historis yang menimbulkan diskriminasi terhadap perempuan bercadar.

Sebagaimana Sudirman (2019) mengatakan bahwa Keterkaitan perempuan bercadar dikategorikan sebagai perempuan muslim yang taat, sering adanya persepsi bahwa jilbab adalah identitas perempuan radikal ${ }^{2021}$. Sedangkan menurut Lisa Aisyiyah Rosid (2018) Dimana hukum penggunaan cadar bagi perempuan muslim secara normative bisa saja menjadi wajib disuatu wilayah bila dijadikan kesepakatan bersama dan menjadi norma yang diterima secara social ${ }^{2223}$. Berbeda dengan Indra Tanra dkk. (2015) perempuan yang bercadar dipengaruhi dari luar yaitu paksaan dari suami dan tuntutan organisasi sehingga menimbulkan perepsi negative dari

\footnotetext{
${ }^{19}$ Syuqqah, Abdul Halim Abu. 2008. Al-Niqâb fi Syari at al-Islam, Beirut: Dar al-Fikr

${ }^{20}$ Muh Sudirman, "Cadar Bagi Wanita Muslimah( Suatu Kajian Perspektif Sejarah )," Diktum jurnal syariah dan bukum 17, no. 1 (2019): 49-64.

${ }^{21}$ Sudirman, M. (2019). Cadar bagi Wanita Muslimah( Suatu Kajian Perspektif Sejarah ). Diktum Jurnal Syariah Dan Hukum, 17(1), 49-64. https://doi.org/doi.org/10.35905/diktum.v17i1.651

${ }^{22}$ Lisa Aisiyah Rasyid, "Problemtika Hukum Cadar Dalam Islam: Sebuah Tinjauan Normatif-Historis Problematics."

${ }^{23}$ Lisa Aisiyah Rasyid, R. B. (2018). Problemtika hukum cadar dalam islam: sebuah tinjauan normatifhistoris Problematics. Jurnal Ilmiah Al-Syir'ah, 7492. https://doi.org/http://dx.doi.org/10.30984/jis.v16i1
} 
masyarakat ${ }^{2425}$. Dari tiga jenis penelitian tersebut sama-sama mengatakan bahawa perempuan bercadar identik dengan radikalisme, terorisme dan aliran sesat. Sedangkan penelitian ini akan mengarah pada emansipasi perempuan bercadar dikaji secara teori hegemoni bahwa diskriminasi yang dilakukan oleh pemerintah dan masyarakat bukanlah hal yang dibenarkan.

Hegemoni Gramsci mengacu kepada hubungan antara apa yang disebutnya "civil society” dan "state" atau negara, di mana keduanya ada pada level superstruktur. Gramsci kemudian menjelaskan peran penting kaum intelektual dalam konsep hegemoninya. Menurut Gramsci, hubungan antara kaum intelektual dan wilayah produksi (dalam istilah Marx hubungan produksi) bersifat tidak langsung, tidak seperti kelompok-kelompok sosial yang secara fundamental masuk ke dalam hubungan tersebut (misal: buruh, pemiliki modal), tetapi dalam tingkat yang berbeda, yang "dimediasi" oleh keseluruhan produksi yang dihasilkan masyarakat dan kompleksitas wilayah superstruktur, di mana kaum intelektual merupakan para "fungsionaris-nya" 2627.

Sehingga muncul permasalahan adanya diskriminasi penggunaan cadar di Indonesia yang menimbulkan larangan penggunaan cadar di kampus yang kemudian timbul sebuah kritik terhadap larangan bercadar tersebut melalui perspektif teori hegemoni.

\section{METODE PENELITIAN}

\section{Penelitian Kualitatif Fenomenologi}

Penelitian ini menggunakan jenis kualitatif dengan desain studi fenomenologi. Penelitian kualitatif adalah penelitian yang secara bolistik bermaksud memahami fenomena tentang apa yang dialami subjek penelitian, baik itu perilakunya, persepsi, motivasi maupun tindakannya, dan secara deskripsi dalam bentuk kata-kata dan bahasa, pada suatu konteks khusus yang alamiah dan dengan memanfaatkan berbagai metode alamiah (Moleong, 2007) ${ }^{28}$ Penelitian yang menggunakan pendekatan fenomenologis berusaha untuk memahami makna peristiwa serta interaksi pada orang-orang biasa dalam situasi tertentu Pendekatan ini menghendaki adanya sejumlah asumsi yang berlainan dengan cara yang digunakan untuk mendekati perilaku orang dengan maksud menemukan "fakta" atau "penyebab (Subadi, 2006) ${ }^{29}$

Peneliti berusaha memahami subyek dari sudut pandang subyek itu sendiri, dengan tidak mengabaikan membuat penafsiran, dengan membuat skema konseptual. Hal ini berarti bahwa peneliti menekankan pada hal-hal subyektif, tetapi tidak menolak realitas "di sana" yang ada pada manusia dan yang mampu menahan tindakan terhadapnya. (Subadi, 2006) ${ }^{30}$.

Memahami makna peristiwa yang dimaksud disini adalah adanya larangan tertulis berupa Surat Keputusan Rektor terhadap pengguna cadar di lingkungan instansi dan pemerintah, khususnya di lingkungan kampus di Universitas Islam di Kota Malang. Sehingga dalam hal ini, menimbulkan asumsi pada kelas elit bahwa pengguna cadar identik dengan radikalisme. Sesuai

24 Syarifuddin Indra Tantra, Nursalam, "Persepsi Masyarakat Tentang Perempuan Bercadar," Equilibrium: Jurnal Pendidikan 3, no. 1 (2015): 116-125.

${ }^{25}$ Indra Tantra, Nursalam, S. (2015). Persepsi Masyarakat Tentang Perempuan Bercadar. Equilibrium: Jurnal Pendidik.an, 3(1), 116-125. https://doi.org/10.26618/equilibrium.v3i1.519

${ }^{26}$ Daniel Hutagalung, "Hegemoni, Kekuasan Dan Ideologi," Jurnal Pemikiran Sosial, Politik dan Hak. Asasi Manusia 74, no. 12 (2004): 1-17.

${ }_{27}$ Hutagalung, D. (2004). Hegemoni, Kekuasan dan Ideologi. Jurnal Pemikiran Sosial, Politik Dan Hak Asasi Manusia, 74(12), 1-17.

${ }^{28}$ Moleong, Lexy J. 2007. Metodologi Penelitian Kualitatif Edisi Revisi. Bandung: Remaja Rosdakarya.

29 Subadi, T. (2006). metode Penelitian Kualitatif (1st ed.; E. Farida, ed.). Surakarta: Muhammadiyah Universitas Press

30 Subadi, T. (2006). metode Penelitian Kualitatif (1st ed.; E. Farida, ed.). Surakarta: Muhammadiyah Universitas Press

Volum 3, Nomor 1, Januari 2020 | 43 
dengan permasalahan penelitian, yang menjadi subjek penelitian dikhususkan pada perempuanperempuan di kampus Universitas Islam Malang, dan Universitas Islam Negeri Maulana Malik Ibrahim Malang di Malang. Jumlah subjek penelitian ditentukan sebanyak 5 orang perempuan. Penelitian dilakukan selama 4 bulan, dari bulan September sampai Desember 2019.

\section{TEORI HEGEMONI ANTONIO GRAMSCI}

Hegemoni muncul dari aliensi karl marx tentang perkembangan ilmu ekonomi politik, karl Marx merefleksikan alienasi telah membawa manusia kepada satu titik dimana manusia sudah tidak lagi mengenal dirinya, dan juga memahami bahwa keterasingan manusia dari kesosialanya diproduksi dalam pekerjaan dibawah sistem ekonomi kapitalis. Keterasinganmanusiamerupakan hasil dari penindasasn dari satu kelas oleh kelas lainnya, maka emasipasi dari keterasingan itu hanya dapat tercapai melalui perjuangan kelas.

Teori hegemoni Gramci Pertama, menerapkan konsep itu lebih luas bagi supremasi satu kelompok atau lebih atas lainnya dalam setiap hubungan sosial, sedangkan pemekaian istilah itu sebelumnya hanya menunjuk pada relasi antara proletariat dan kelompok lainnya. Kedua, Gramci juga mencirikan hegemoni dalam istilah "pengaruh kultural", tidak hanya "kepemimpinan politik dalam sebuah sistem aliansi” sebagaimana dipahami generasi Marxis terdahulu (Femia, 1983).

Menurut Gramci ada tiga tingkatan hegemoni, yaitu hekemoni total (integral) hegemoni yang merosot (decadent) dan hegemoni yang minimum.

Hegemoni integral ditandai dengan afiliasi massa yang mendekati totalitas. Masyarakat menunjukkan tingkat kesatuan moral dan intelektual yang kokoh ini tampak dari hubungan organis pemerintah dan yang diperintah. Hubungan ini tidak diliputi dengan kontradiksi dan antagonisme baik secara sosial maupun etis. (Surbakti, 2010). Adanya argumen pemerintah yang mempengaruhi masyarakat melalui media, surat keputusan presiden, surat keputsan universitas dan statmen- statmen pemuka agama dari kelompok tertentu tentang pelaranga memakai cadar mengakibatkan stigma radikalisme dan terorisme terhadap pengguna cadar.

Hegemoni yang merosot ditandai dengan adanya tantangan berat yang dihadapi kaum borjuis di era masyarakat kapitalis moderen. Menurut Gramsci pada tahap ini terjadi potensi disintegrasi atau potensi konflik yang tersembunyi dibawah permukaan. Artinya, sekalipun sistem yang ada telah mencapai kebutuhan dan sasaranya, namun mentalitas massa tidak sungguhsungguh selaras dengan pemikiran yang dominan dan subjek yang hegemoni. (Surbakti, 2010) Timbul pemikiran mengenai terorisme terhadap pengguna cadar berawal dari banyaknya kasus bom bunuh diri yang dilakukan oleh kelompok organisasi islam seperti pada kasus bom bali, bom JW Marriott dan Ritz-Carlton dan menara kembar World Trade Center di New York. Amerika Serikat hal ini selalu dikaitkan dengan islam garis kelas termasuk kelompok pengguna cadar. Ketakutan pemerintah sebagai sebuah sistim organisasi terhadap islam garis keras menimbulkan berbagai peraturan-peraturan baru yang mengarah kepada tindakan diskriminasi terhadap perempuan bercadar.

Hegemoni minimum, yaitu situasi yang menurut Gramsci terjadi di Italia dari periode unifikasi sampai pertengahan abad IX. Hegemoni yang berkembang pada tahap ini bersandar pada kesatuan ideologis antara elit ekonomi, politik, dan intelektual yang berlangsung bersamaan dengan keengganan terhadap setiap campur tangan massa dalm hidup bernegara. Alih-alih menyesuaikan dengan kepentingan dan aspirasi mereka dengan masyarakat, mereka malah mempertahankan peraturan melali transformasi penyatuan para pemimpin budaya, politik, sosial, maupun ekonomi yang secara potensial bertentangan dengan negara baru yang diciptakan oleh kelompok hegemoni itu (Surbakti, 2010). Media massa secara tidak langsung telah berkontribusi dalam tindakan 
diskriminasi terhadap perempuan bercadar ditandai dengan sorotan media yang selalu mengarah pada perempuan bercadar dengan tindakan radikalisme seperti terorisme, fanatisme dan aliran sesat.

Dalam pandangan Gramsci hubungan antara Outcome Power (kemampuan dari aktor/subyek untuk membawa atau membantu menghasilkan sesuatu (outcomes)) dan Social Power (kemampuan dari aktor/subyek secara deliberatif mengubah struktur insentif dari aktor atau aktoraktor lainnya untuk membawa serta atau membantu menghasilkan sesuatu) bisa berupa hubungan dominasi langsung atau bisa juga merupakan hubungan yang hegemonik. Bagaimana membedakannya adalah bagaimana praktik itu dijalankan (exercise). Pada bagian ini akan coba diuraikan berbagai perspektif dalam melihat power relation (hubungan kuasa) secara teoritis ${ }^{3132}$.

\section{DISKRIMINASI PENGGUNAAN CADAR DI INDONESIA}

Pada tahun 1982 Presiden Suharto ia menerbitkan surat keputusan Presiden No. 052.c/Kep/ D 82 tentang Pedoman Pakain Seragam sekolah, dimana dalam peraturan tersebut ditegasakan bahwa adanya larangan penggunaan pakaian jilbab pada lingkup birokrasi pendidikan. Larangan tersebut merupakan sebuah tindakkan yang mengarah pada adanya diskriminasi terhadap kelompok agama islam pada saat itu. Keputusan itu memicu protes dari para cendekiawan dan aktivis Islam hingga pada tahun 1991 prseiden mencabut pelarangan penggunaan jilbab di sekolah. Dalam SK yang baru itu, SK No. 100/C/Kep/D/1991, tidak disebutkan kata jilbab, tetapi yang digunakan adalah istilah "seragam khas." Dalam peraturan tersebut, dinyatakan "Siswi (SMP dan SMA) yang karena keyakinan pribadinya menghendaki penggunaan pakaian seragam sekolah yang khas dapat mengenakan pakaian seragam khas yang warna dan rancangan sesuai lampiran III dan IV." Pada lampirannya bisa dilihat bentuk seragam khas yang dimaksud, yang tidak lain adalah busana muslimah dengan jilbab atau jilbabnya. (https://jejakislam.net/perjuangan-panjang-jilbab- diindonesia/).

Ada beberapa pendapat mazhab tentang penggunaan cadar seperti hukum mewajibkan penggunaan cadar dan hukum makruh pada penggunaan cadar, dalam madzhab Malikiyyah: "Makruh bagi seorang perempuan menutup wajahnya dengan niqab sesuatu yang menutupi mata saat melakukan salat, karena bal itu termasuk berlebib-lebihan (ghuluw) lebib-lebih bagi laki-laki”. Kemakruhan ini berlaku selama penggunaan niqab bukan bagian dari adat atau tradisi setempat ${ }^{3334}$.

Dalam tataran praksisnya penggunaan cadar tidak bisa dilepaskan konteks sosial budaya masyarakat setempat. Artinya, penggunaan cadar di sebuah daerah yang memiliki kultur yang cocok dengan pakaian tersebut tidak menjadi sebuah masalah. Seperti yang dikatakan Aulia 2013 bahwa pengunaan pakaian rimpu mpida di Bima bukanlah sebuah masalah besar, karena rimpu mpida merupakan simbol bagi perempuan yang belum menikah. Rimpu mpida sendiri ialah jenis pakaian sarung cadar khas daerah Bima. Hal ini menunjukan budaya yang diciptakan oleh para mubalig mengajarakan bagaimana hukum pakaian islam pada saat itu dan menjadi budaya pakaian pada masyarakat sampai saat ini ${ }^{3536}$.

${ }^{31}$ Hutagalung, "Hegemoni, Kekuasan Dan Ideologi."

${ }^{32}$ Hutagalung, D. (2004). Hegemoni, Kekuasan dan Ideologi. Jurnal Pemikiran Sosial, Politik Dan Hak Asasi Manusia, 74(12), 1-17.

${ }^{33}$ Sudirman, "Cadar Bagi Wanita Muslimah( Suatu Kajian Perspektif Sejarah )."

${ }^{34}$ Sudirman, M. (2019). Cadar bagi Wanita Muslimah( Suatu Kajian Perspektif Sejarah ). Diktum Jurnal Syariah Dan Hukum, 17(1), 49-64. https://doi.org/doi.org/10.35905/diktum.v17i1.651

35 Rihlah Nur Aulia, "Rimpu: Budaya Dalam Dimensi Busana Bercadar Perempuan Bima," Jurnal Studi Al-Qur an 9, no. 2 (2013): 94-108. 
Larangan penggunaan cadar pada Universitas Islam di daerah Malang Razasudah terjadi pada tahun 2018. Sepertipada Universitas Islam Malang yang melarang penggunaan cadar pada mahasiswa. Pelarangan penggunaan cadar tertulis dalam Keputusan Rektor Unisma nomor 676/G152/U.KPK/R/1.16/X/2018 tentang Peraturan Berpakaian di dalam Kampus atau kegiatan atas nama Unisma. Persisnya, dalam Pasal 1 ayat $1 \mathrm{~b}$ tentang Aturan Berpakaian Muslim. Begitu juga dengan peraturan Kemahasiswaan Universitas Islam Negeri Maulana Malik Ibrahim Malang pada tgl 13 Agustus 2018, terdapat salah 1 peraturan yakni dilarangnya memakai penutup wajah/cadar selama pelaksanaan PBAK- U/OSPEK kampus. Larangan penggunaan cadar pada mahasiswa merupakan diskriminasi terhadap kepercayaan dan hukum agama tertentu pada individu. Sebagai Universitas Islam yang memahami adanya beberapa mazdhab tertentu tentang hukum penggunaan cadar tidak seharusnya Universitas mengeluarkan peraturan yang mengarah pada tindakan diskriminasi terhadap penganut mazdhab tertentu.

Menurut KBBI diskriminasi merupakan pembedaan perlakuan terhadap sesama warga negara (berdasarkan warna kulit, golongan, suku, ekonomi, agama, dan sebagainya). Diskriminasi penggunaan cadar terjadi akibatnya banyaknya isu terorisme dan radikalisme yang terjadi di Indonesia. Diskriminasi akan terus tejadi apabila pembedaan perlakukan pemerintah masyarakat dan budaya yang mengatakan bahwa perempuan bercadar merupakan bagian dari kelompok radikal yang mengarah pada tindakan teorisme. Stigma negatif tersebut yang melahirkan diskriminasi bagi orangorang yang bercadar. Media juga menjadi salah satu penyebar kebencian mengenai cadar. Di media sering diperlihatkan orang bercadar terkait dengan aliran keras, radikal dan teroris ${ }^{3738}$. Permasalahannya cadar seringkali diasosiasikan dengan atribut organisasi Islam yang fanatik, fundamental dan garis keras ${ }^{3940}$. Cadar adalah kain penutup kepala yang diletakkan oleh para perempuan pada ujung hidungnya dan menutup wajah dengannya. Dasar dari penggunaan cadar adalah untuk menjaga perempuan sehingga tidak menjadi fitnah dan menarik perhatian laki-laki yang bukan mahramnya. Perempuan Muslimah disyariatkan untuk menutup wajah dan aurat mereka di depan lelaki ajnabi(non mahram) ${ }^{4142}$.

\section{LARANGAN PENGGUNAAN CADAR DI KAMPUS}

Bercadar adalah keyakinan pribadi. Setiap keyakinan itu tergantung pembacaannya terhadap teks atau bisa jadi karena itba' pada qawl ulama (minoritas). Maka termasuk kategori khilafiyah dan amalannya tidak wajib. Demikian melarangnya juga bukan sesuatu yang melanggar hukum. Kecuali keyakinan itu sesuatu yang muttafaq 'alaih (yang disepakati) baru dikategorikan melanggar UUD 1945.

${ }^{36}$ Aulia, R. N. (2013). Rimpu: Budaya Dalam Dimensi Busana Bercadar Perempuan Bima. Jurnal Studi Al-Qur An, 9(2), 94-108.

37 Reni Juliani, "Stigmatisasi Mahasiswa Tentang Maraknya Mahasiswa Bercadar Di Kampus," Jurnal Community 4, no. 1 (2018): 90-104; Suci Maya Tirta, "KOMUNIKASI INTERPERSONAL MAHASISWI MUSLIM BERCADAR DALAM BERSOSIALISASI DI LINGKUP KAMPUS," JISIP: Jurnal Ilmu Sosial dan Ilmu Politik 7, no. 3 (2018): 124-131.

38 Juliani, R. (2018). Stigmatisasi Mahasiswa Tentang Maraknya Mahasiswa Bercadar Di Kampus. Jurnal Community, 4(1), 90-104. https://doi.org/24775746

Tirta, S. M. (2018). Komunikasi interpersonal mahasiswi muslim bercadar dalam bersosialisasi di lingkup kampus. JISIP: Jurnal Ilmu Sosial Dan Ilmu Politik, 7(3), 124-131. https://doi.org/24426962

${ }^{39}$ Ratri, "Cadar, Media, Dan Identitas Perempuan Muslim."

40 Ratri, L. (2011). Cadar, Media, Dan Identitas Perempuan Muslim. Topik Utama, 39(2), 29-37

${ }^{41}$ Mujahidin Mujahidin, "Cadar: Antara Ajaran Agama Dan Budaya," JUSPI Jurnal Sejarah Peradaban Islam) 3, no. 1 (2019): 11.

42 Mujahidin, M. (2019). Cadar: Antara Ajaran Agama dan Budaya. JUSPI (Jurnal Sejarah Peradaban Islam), 3(1), 11. https://doi.org/10.30829/juspi.v3i1.3142 
Ibadah yang muttafaq alaih seperti sholat dan puasa Ramadlan ${ }^{4344}$. Dari hasil penelitian yang berasal dari beberapa sumber mengatakan bahwa larangan penggunaan cadar sudah mengarah pada tindakan diskriminasi dan intoleransi terhadap kelompok tertentu. Seperti yang dikatakan oleh salah satu mahasiswa Universitas Islam Negeri Malik Ibrahim Indi Faiza (19) bahwa " (tindakan) ini tidak menghargai muslimah yang ingin menjalankan syariat islam yang merupakan sunah Rosulullah yakni memakai cadar" hal ini diperkuat dengan argumen Nurhayati Wahidayah (23), "akibat adanya larangan menggunakan cadar kita mahasiswi sampai dilarang menggunakan masker di wilayah kampus apa lagi dalam ruang kelas". Begitujuga dengan Dwi Jayanti N. (22) "itukan identitas agama, tidak perlu lab di atur-atur tob Indonesia adalah negara demokrasi Pancasila, ga seharusnya bersikap rasis kaya gitu” Hal ini menunjukkan bahwa peraturan yang dikeluarkan oleh Universitas mengakibatkan perempuan tidak dapat mengekspresikan diri melalui pakaian dan kepercayaannya sehingga menciptakan adanya marginalisasi terhadap kelompok tertentu di lingkungan kampus. Dilihat dari perspektif hegemoni bahwa tindakan yang dilakukan oleh Rektor pada Universitas Agama Islam selaku kaum borjuis sebagai pemilik kekuasaan secara tidak langsung menekan kelas proletar (perempuan bercadar/ mahasiswa bercadar) dengan menggunakan ideologi agama pahwa paham-paham pengguna cadar sangat tidak sesuai dengan sariat yang ada di wilayah kampus sehingga dengan kekuasaannya tersebut Rektor serta pihak kampus mengeluarkan peraturan penggunaan cadar yang menimbulkan adanya tindakan diskriminasi terhadap kelas minoritas.

\section{KRITIK TERHADAP LARANGAN BERCADAR MELALUI PERSPEKTIF HEGEMONI}

Kemampuan dari dua Rektor Universitas Islam di Kota Malang membawa atau membantu menghasilkan sesuatu yaitu ketakutan terhadap pengguna cadar yang mendikte bahwa pengguna cadar ialah sosok yang dekat dengan terorisme dan radikal. Hegemoni mengikutsertakan kelas-kelas lain dengan mendapatkan dukungan aktif mereka. Hal ini hanya bisa terjadi kalua bagian yang dominan mampu mengatasi kepentingan "korporatisnya" untuk melibatkan diri dengan massa popular (Bellamy, 1990)45. Yang kemudian Rektor tesebut menggunakan kekuasaannya sebagai kelas elit mengubah struktur formal dari sebuah universitas untuk membawa serta seluruh struktur lembaga organisasi universitas termasuk didalamnya mahasiswa, dosen dan tekhnisi lingkup kampus untuk mendukung dan menjalankan Surat Keputusan tertentu baik di lingkup lembaga internal ataupun di eksternal kampus. Hubungan ini menurut gramsci, berupa hubungan dominasi langsung yang dilakukan oleh si penguasa terhadap yang dikuasai.

Konsepsi hegemoni Gramsci merujuk pada kedudukan ideologis satu atau lebih kelompok atau kelas dalam masyarakat sipil yang lebih tinggi dari yang lainnya (Bellamy, 1990)46. Gramsci mengacu kepada hubungan antara apa yang disebutnya "civil society" dan "state" atau negara, di mana keduanya ada pada level superstruktur. Gramsci kemudian menjelaskan peran penting kaum intelektual dalam konsep hegemoninya. Menurut Gramsci, hubungan antara kaum intelektual dan wilayah produksi (dalam istilah Marx hubungan produksi) bersifat tidak langsung,

43 Fathonah K. Daud, "Tren Jilbab Syari Dan Polemik Cadar Mencermati Geliat Keislaman Kontemporer Di Indonesia," Proceedings of Annual Conference for Muslim Scholars, no. 1 (2018): 39-53.

44 Daud, F. K. (2018). Tren Jilbab Syari dan Polemik Cadar Mencermati Geliat Keislaman Kontemporer di Indonesia. Proceedings of Annual Conference for Muslim Scholars, (1), 39-53.

45 Bellamy, Richard, 1990. Teori Sosial Modern: Modern Italia Social Theory Terjemahan Vedi R. Hadiz. Jakarta: LP3ES

${ }_{46}$ Bellamy, Richard, 1990. Teori Sosial Modern: Modern Italia Social Theory Terjemahan Vedi R. Hadiz. Jakarta: LP3ES 
tidak seperti kelompok-kelompok sosial yang secara fundamental masuk ke dalam hubungan tersebut (misal: buruh, pemiliki modal), tetapi dalam tingkat yang berbeda, yang "dimediasi" oleh keseluruhan produksi yang dihasilkan masyarakat dan kompleksitas wilayah superstruktur, di mana kaum intelektual merupakan para "fungsionaris-nya" ${ }^{47} 48$

Gramsci membedakan dua jenis intelektual: 'tradisional' dan 'organik'. Anggota kelompok pertama "mengajukan diri sebagai otonom dan merdeka dari kelompok social dominan", sebaliknya kaum intelektual "organic" mengakui hubungan mereka dengan kelompok social tertentu dan memberikan "homogenitas serta kesadaran tentang fungsinya, bukan saja dibidang ekonomi tetapi juga di bidang social dan politik. Gramsci mengubah makna intelektual tak merujuk pada strata yang biasanya dimaksud dengan istilah jenis intelektual tetapi secara umum seluruh strata social melaksanakan fungsi organisasi dalam arti yang lebih luas apakah dibidang produksi kebudayaan atau administrasi politik (Bellamy, 1990) ${ }^{49}$. Actor dalam kelompok intelektual tradisonal Gramsci adalah kaum elit yang memiliki kepentingan sebagai otonom dari kelompok social yang akan didominasi. Kaum elit pihak kampus sebagai pemilik kekuasaan yang memiliki kepentingan di kampus berperan sebagai actor otomom yang mendominasi mahasiswa sebagai agen produksi yang didominasi. Hegemoni Gramsci dapat dilakukan secara langsung dan tidak langsung tergantung dari bagamana para elit melakukan tindakan sesuai dengan kepentingan.

Hegemoni yang dilakukan oleh Rektor pada kedua Universitas Islama yang berada dikota Malang secara langsung di wilayah struktur universitas, sedangkan dalam teori Gramsci, hegemoni yang dilakukan oleh kaum elit bersifat tidak langsung, menurutnya, hegemoni terjadi melalui peran para kelas elit yang dimaksud disini yaitu para tokoh pemerintah selaku penguasa dan masyarakat sipil selaku individu yang dikuasai. Jadi, antara teori hegemoni Gramsci dengan Fenomena Diskriminasi terhadap perempuan bercadar mempunyai perbedaan pada subjek ataupun actor dan struktur yang dikuasainya.

\section{KESIMPULAN}

Dengan melihat adanya fenomena pelarang menggunakan cadar diuniversitas islam malang oleh Rektor Universitas Islam Negeri Maulana Malik Ibram dan Universitas Islam Malang membuktikan adanya diskriminasi yang dilakukan oleh pemerintah atau elit terhadap seseorang atau kelompok yang menggunakan cadar. Hal ini sesuai dengan teori Hegemoni Antonio Gramsci yang mengatakan bahwa dominasi bukanlah hubungan dengan menggunakan kekuasaan melainkan hubungan persetujuan dengan menggunakan kepemimpinan politik dan ideologi. Ketakutan terhadap islam radikal mengakibatkan munculnya peraturan-peraturan yang mengarah pada tidakan diskriminasi terhadap perempuan bercadar.

\section{REFERENSI}

Andiko, Toha. "Larangan Bercadar Di Perguruan Tinggi Perspektif Sadd Al-Dzarî’ah.” Madania: Jurnal Kajian Keislaman 22, no. 1 (2018): 113.

${ }^{47}$ Hutagalung, "Hegemoni, Kekuasan Dan Ideologi."

48 Hutagalung, D. (2004). Hegemoni, Kekuasan dan Ideologi. Jurnal Pemikiran Sosial, Politik Dan Hak Asasi Manusia, 74(12), 1-17.

49 Bellamy, Richard, 1990. Teori Sosial Modern: Modern Italia Social Theory Terjemahan Vedi R. Hadiz. Jakarta: LP3ES 
Aulia, Rihlah Nur. "Rimpu: Budaya Dalam Dimensi Busana Bercadar Perempuan Bima." Jurnal Studi Al-Qur an 9, no. 2 (2013): 94-108.

Daud, Fathonah K. "Tren Jilbab Syari Dan Polemik Cadar Mencermati Geliat Keislaman Kontemporer Di Indonesia." Proceedings of Annual Conference for Muslim Scholars, no. 1 (2018): 39-53.

Dewi, Putri Aisyiyah Rachma. "Niqab Sebagai Fashion: Dialektik Konservatisme Dan Budaya Populer.” Scriptura 9, no. 1 (2019): 9-15.

Hutagalung, Daniel. "Hegemoni, Kekuasan Dan Ideologi.” Jurnal Pemikiran Sosial, Politik dan Hak Asasi Manusia 74, no. 12 (2004): 1-17.

Indra Tantra, Nursalam, Syarifuddin. "Persepsi Masyarakat Tentang Perempuan Bercadar." Equilibrium: Jurnal Pendidikan 3, no. 1 (2015): 116-125.

Juliani, Reni. "Stigmatisasi Mahasiswa Tentang Maraknya Mahasiswa Bercadar Di Kampus." Jurnal Community 4, no. 1 (2018): 90-104.

_. "Stigmatisasi Mahasiswa Tentang Maraknya Mahasiswa Bercadar Di Kampus." Jurnal Community 4, no. 1 (2018): 90-104.

Kurniawan, Budi. "Rethinking Cadar Banning in Indonesia's Higher Education: Questioning Freedom of Religion and Positioning Fear of Radicalism." SHS Web of Conferences 54 (2018): 02004.

Lisa Aisiyah Rasyid, Rosdalina Bukido. "Problemtika Hukum Cadar Dalam Islam: Sebuah Tinjauan Normatif-Historis Problematics.” Jurnal Ilmiah Al-Syir'ah 16, no. 1 (2018): 7492.

Mujahidin, Mujahidin. “Cadar: Antara Ajaran Agama Dan Budaya.” JUSPI Jurnal Sejarah Peradaban Islam) 3, no. 1 (2019): 11.

Qolbi, Khamdan. "Makna Penggunaan Cadar Mahasiswi Institut Keislaman Abdullah Faqih ( INKAFA )." Jurnal Paradigma 1, no. 3 (2013): 1-4.

Rahman, Alif Fathur, and Muhammad Syafiq. "Motivasi, Stigma Dan Coping Stigma Pada Perempuan Bercadar.” Jurnal Psikologi Teori dan Terapan 7, no. 2 (2017): 103.

Ratri, Lintang. "Cadar, Media, Dan Identitas Perempuan Muslim.” Topik Utama 39, no. 2 (2011): 29-37.

Sudirman, Muh. “Cadar Bagi Wanita Muslimah( Suatu Kajian Perspektif Sejarah ).” Diktum jurnal syariah dan bukum 17, no. 1 (2019): 49-64.

Tirta, Suci Maya. "KOMUNIKASI INTERPERSONAL MAHASISWI MUSLIM BERCADAR DALAM BERSOSIALISASI DI LINGKUP KAMPUS." JISIP: Jurnal Ilmu Sosial dan Ilmu Politik 7, no. 3 (2018): 124-131. 